\title{
P.N. OPARA
}

ABSTRACT

It has been observed that the price of roofing sheets and building materials in General are increasing on daily bases. All efforts by the government to reduce the price has proved abortive. Also rice husk is wasting in dumps. Rice husk dumps constitute environmental. pollution and degradation. Hence, the focus of the research is to make rice husk useable in the production of corrugated roofing sheets, and also solve the problem of wastage of rice husk. To carry out the study, the researcher used risk husk, cement, waste paper and additives such as marble dust and red oxide pigment. The rice husk was treated and used to produce corrugated roofing sheets. Rise Husk could not be used effectively without special treatment. The samples produced were tested for water absorption, water permeability, breaking load, fire resistance and surface defects. The result of the study revealed that rice husk corrugated roofing sheets compared favourably with Asbestos roofing sheets. The rice husk can be used to replace asbestos in the production of corrugated roofing sheet considering that asbestos causes cancer and has been banned in the western world.

Key words: Rice husk, roofing sheet

\section{INTRODUCTION}

A study of local raw materials for construction is an area of human endeavour, which related to the socio-economic aspect of life, This is due to the fact that the capacity of an individual nation in science and technology can often be used to enhance her economic, social and environmental development. In order to overcome the problem of over - dependence on conventional building materials, efforts have been directed towards the local sourcing of alternative building materials. It was against this background that the Nigerian Building and Road Research (NBRRI) was cstablished in 1978. In its programme for the national development plan, NBRRI placed emphasis on the development of suitable local building materials at little or no cost. Rice husk is one of the agro-industrial waste being wasted for many years in Nigeria. Therefore, it has become necessary to look for a way of making rice husk a uscable raw material in the production of corrugated roofing sheets. Ricc husk is produced in most states in Nigeria such as Anambra State. Enugu State, Delta State, Edo State, Imo State, Ebonyi State, Kogi State, Cross River State, Kaduna State, Kano State, Kwara State, Nigeria State, Lagos State, Ogun State, Ondo State, Etiti State, River State, Benue State, Plateau State, Sokoto State, Kiebbi State, and Federal Capital Territory. The cites in Nigeria where rice is massively grown and produced are Abakiliki, Afikpo, Ogija, Odoro, Ikepe, Lafiagi, Badeggi, Pategi, Sokoto, Birnin Kebbi, Abeokuta, Benin and Delta region source: Nigerian cereals Research Institute Baddegi - annual report 1992.

Hence, rice husk can be said to be in commercial quantity in Nigeria to support rice husk roofing sheets industries. For Nigeria to move towards the reduction of the price of building materials, locally sourced material and locally built equipment are necessary.

The building industry in Nigeria is plagues by shortage of construction materials. The situation is compounded by the high cost of conventional building materials most of which are imported. The pillar of housing and other real estate market are beyond the reach of the ordinary Nigeria. Thus people have difficulties building house of their own. Tenants are living in constant fear of shylock landlords. Who increase house rents arbitrarily and also issue quite random. Rice husk is usually found in heaps by the roadsides, riverbanks or 


\section{Journal Of Agriculture and Social Research (JASR) Vol. 6, No.1, 2006}

nearby buildings. The evacuation of the heaps of rice husk form the environment has become a big problem. The heaps of rice husk contribute immensely to environmental pollution, degradation and hazards. In an attempt to dispose of rice husk, most communities put fire on it. Unfortunately, a small heap of rice husk takes months to get burnt to ashes. Even when burnt to ashes, it is an cyc sore in the towns especially during the rainy season. Rice husk dumps, which are on fire, constitute a serious hazard in the community. Hence it has become necessary to rid the environment of rice of husk wastes and to make it be of some positive economic importance to Nigeria. This, this study is to examine the use of rice husk in the production of corrugated roofing sheets. The purpose of this study is to make rice husk useable in the production of corrugated roofing sheets. The study is important because it will provide information necessary for the production of corrugated roofing sheets using rice husk. Thus the environmental pollution, degradations and hazards posed by rice dumps will be reduced. The wastage of rice husk will be minimized. Rice husk roofing sheet industries will provide employment opportunities for Nigerians. The use of rice husk in the production of corrugated roofing sheet will encourage many more people into rice farming since both the rice and husk will be sold for money. Unlike asbestos roofing sheet, rice husk roofing sheet does not pose health problem to the inmates or those working with rice husk. Besides, it has most of the qualities which asbestos has a roofing material. It was assumed in the study that the properties of rice husk are the same regardless of where the rice was grown.

\section{METHODOLOGY}

The method of research used in this study is action research. The materials used in the production of rice husk roofing sheets includes:
1. Portland cement
2. Clean dry rice husk
3. Waste paper
4. Marble dust
5. Clean water

Fine particles of rice husk were used. This is because ABA (1996) revealed that the particles size of materials have influence on the strength and workability of the concrete. Four batches of rice husk were used in the study. Three out of the four batch were treated. Sample A by lime Samples B was treated by burning and Sample C was treated by boiling. The forth batch called sample $D$ was not treated. It was used as a control experiment.

Each batch of rice husk was mixed with cement, marble dust, waste paper and clean water respectively. The mixtures were used to produce roofing sheets.

\section{Procedure for the production of Rice Husk Roofing Sheets}

Fredrick (1975) recorded that the mix proportion for the production of asbestos roofing sheets is $15-25$ percent asbestos fibre and $75-85$ percent Portland cement. This percentage ratio was used in the production of the rice husk roofing sheets.

The ratio of mix was made in the following proportion by mass

Waste paper

Rice Husk

5 pereent

Cement

15 percent

80 percent

The ratio therefore is $1: 316$.

Also the British Standard Bs 690 (part 5) (1975) for roofing sheet requires that the roofing sheet shall be made from a close and homogeneous mixture consisting essentially of suitable inorganic hydraulic binder (cement). Asbestos fibre, and water and shall exclude any 
material manufactured in there natural colour or may be coloured by the addition of pigment suitable for colouring asbestos product, or have adherent pigment or unpigmented coatings applied to their surfaces for the purposes of decoration. Marble dust is added to the mixture to serve as a filler. It is pertinent to note that except rice husk is treated it cannot used as a building material. $\mathrm{R}-\mathrm{S}$ machine was used to mould mixture into corrugation roofing sheets.

\section{Tests carried Out}

The roofing sheets were tested for permeability, water absorption density, breaking, load, and surface defect and fire resistance. The test was carried out in order to ascertain the effectiveness of the rice husk roofing sheets. The entire tests were carried out without a period of one month.

\section{RESULT}

Table 1: Characteristics Of Rice Husk When Treated And Unused In The Production Of Roofing Sheet.

\begin{tabular}{|c|c|c|c|c|c|}
\hline Test carried out & $\begin{array}{l}\text { Sample A } \\
\text { Treated by time }\end{array}$ & $\begin{array}{l}\text { Sample B } \\
\text { Treated } \\
\text { burning }\end{array}$ & $\begin{array}{l}\text { Sample } \mathrm{C} \\
\text { boiling }\end{array}$ & \begin{tabular}{|l} 
Sample D \\
Not \\
treated \\
\end{tabular} & Remarks \\
\hline Surface defects & No visible Cracks & $\begin{array}{l}\text { No Visible } \\
\text { Crack }\end{array}$ & $\begin{array}{l}\text { Slight } \\
\text { cracks under } \\
\text { the roofing }\end{array}$ & $\begin{array}{l}\text { Very } \\
\text { brittle }\end{array}$ & $\begin{array}{l}\text { A and B } \\
\text { Acceptance }\end{array}$ \\
\hline Density & $\begin{array}{c}4,94754.00270 \\
0.00270 \\
=1832.41 \\
\end{array}$ & $\begin{array}{l}4240 \\
0.00225 \\
1966.22 \\
\end{array}$ & $\begin{array}{l}4.2050 \\
9.00287 \\
=1465.16 \\
\end{array}$ & $\begin{array}{l}\text { Nill } \\
\text { Nill } \\
\text { Nill } \\
\end{array}$ & $\begin{array}{l}\text { B acceptable } \\
\text { B acceptable }\end{array}$ \\
\hline $\begin{array}{l}\text { Water } \\
\text { permeability }\end{array}$ & Impervious & $\begin{array}{l}\text { Most } \\
\text { Impervious }\end{array}$ & Impervious & Nill & eptance \\
\hline $\begin{array}{l}\text { Water absorption } \\
\text { after } 24 \text { hours }\end{array}$ & $13.42 \%$ & $5.30 \%$ & $12.24 \%$ & Nill & $\begin{array}{l}\text { B } \\
\text { acceptable }\end{array}$ \\
\hline $\begin{array}{l}\text { Breaking load } \\
\mathrm{kg} / \mathrm{mm}\end{array}$ & 80 & 152 & 142 & Nill & $\begin{array}{l}\mathrm{B} \text { and } \mathrm{C} \\
\text { Accountable }\end{array}$ \\
\hline re resistance & Fairly good & Very good & Fairly good & Poor & B acceptance \\
\hline
\end{tabular}

\section{CONCLUSION}

The test result in Table 1 revealed that rice husk can be made useable in the production of corrugated roofing sheets. The result in table 1 also revealed that line is fairly good in the treatment of rice husk in other to make it usable in the production of the corrugated roofing sheets. In the test result it can be seen that Sample B had no visible crack, the density was very high (1966.22), most impervious to water, rate of absorption very low and most ideal $(5,3 \%)$ and a very high breaking load $(150 \mathrm{k} / \mathrm{mm}$ or $15.0 \mathrm{~kg} / \mathrm{cm})$. Though roofing sheets made out of rice husk as seen in Sample A had a fairly good density of $1832.41 \mathrm{~kg} / \mathrm{m}$, the rate of absorption of water is fairly high (13.42\%). Also the breaking load is low $80 \mathrm{~kg} / \mathrm{mm}$ or $8.0 \mathrm{~kg} / \mathrm{cm}$ indicating that it cannot resist impact hence its malleability and resistance was low.

One would have thought: that being a pozolana, rice husk would have been the best for the production of roofing sheets but surprisingly it was not so. A number of reasons may be have been responsible for its low performance. The good properties of rice husk may have been destroyed by the high temperature of $800^{\circ} \mathrm{F}$ to which the rice Husk was exposed in 
order to convert it to ashes. Secondly, the impurities in rice husk may heave been destroyed in the process of heating, its ability to affect the mixture negatively cannot be ruled out. Rice Husk treated by boiling recorded a fairly high breaking load of $142 \mathrm{~kg} / \mathrm{m}$ or $14.2 \mathrm{~kg} / \mathrm{cm}$ and made an acceptable permeability level. This not. withstanding, the rate of absorption of water was fairly high $(12.24 \%)$.

Also the appearance of cracks at the bottom side of the roofing sheet disqualified it as a roofing shect. From the literature review, it was obvious that most of the researchers burnt rice hush before using it as a building material. For now, the best alternative is to remove fat and oil content in rice husk without destroying rice husk itself. From the result of data analysis and findings it is hereby concluded that rice husk can be used in the production of corrugated roofing sheet. Rice husk roofing sheet provides a good alternative that does not pose any health hazard. In most parts of the western world asbestos roofing sheet is no longer being used in the roofing of houses.

\section{REFERENCES}

Adalbert, P.M. (1976) Materials for construction, their manufacture and properties. New York; John Willey and Sons Inc.

Emenari, O. (1987) Analysis of rice husk as cement replacement in Concrete construction. Unpublished Masters Thesis. University of Nigeria, Nsukka.

Fredrick, S.M. (1975) Building design and construction handbook. London: McgrawHill Book company.

Fashaba, C.O. (1994) Partial replacement of cement with rice husk in concrete elements. Unpublished manuscript.

Hornbostel, C. (1991) Construction materials, types uses and application. New York: John Wiley and sons inc.

Kenya Bureau of Standards (1987): Specification for fibre concrete roofing sheets. Bairobi: author.

Onyemachi, G.A (1994) Utilities of rice husk and its derivatives in building industry. Unpublished thesis, University of Nigeria Nsukka. 